\title{
LA POESÍA POPULAR EN LA OBRA DE NICANOR PARRA SANDOVAL
}

\author{
Miguel Naranjo Ríos
}

\begin{abstract}
La poesía popular es una de las fuentes de la que bebe la obra de Nicanor Parra. Esto se palpa en la presencia del canto folclórico, de las frases hechas, de cierto humor ladino y, especialmente, en la rítmica utilizada en muchos de sus poemas. Si bien al madurar la obra de Parra dejó de recurrir a la poesía popular de manera tan explícita, hasta en sus últimas publicaciones hay rastros de esta relación largamente sentida. Después de todo, como bien desarrolla este ensayo, la poesía popular es un alimento que Nicanor Parra recibió desde su infancia y sus seres más cercanos.
\end{abstract}

Popular poetry is one of the main sources employed in the work of Nicanor Parra. It is felt by the presence of folkloric song, typical sayings, a certain cunning humor, and especially in the rhythm used in many of his poems. Although Parra stopped using it explicitly as his work matured, there are still traces of this long-standing relationship even in his last poems. After all, as this essay explains, popular poetry is food that Nicanor Parra received from his beloveds.

\section{UNO}

a poesía popular latinoamericana ha sido resultado de diversas influencias que, a partir de las colonias española y portuguesa, tuvieron su tierra de cultivo en el nuevo continente. Aunque sus orígenes de ultramar son inciertos de ubicar, algunas de estas influencias son

Miguel Naranjo Ríos (Santiago, 1970). Poeta. Autor de Verso (Santiago: Ediciones Tácitas, 2006). Email: miguel.naranjo.rios@gmail.com 
discernibles: la poesía arábigo-andaluza, el oficio de los juglares del medioevo, la religiosidad popular y el romancero y cancionero españoles.

El chileno Desiderio Lizana explica en su libro Cómo se canta la poesía popular (1912) que ésta es principalmente de autor anónimo o improvisada, y que la mayoría de las veces se canta. Y que estos poetas populares, o puetas — como se autodenominan-, son personas con poca instrucción, pero muy hábiles para la música y la ejecución de instrumentos.

Así se entiende que una misma poesía popular, diseminada en diversas versiones por el continente, se interprete de acuerdo con las posibilidades creativas de los habitantes de cada región; por ejemplo, las versiones del romance "Blanca Flor y Filomena" con musicalizaciones distintas tanto en Nicaragua ${ }^{1}$ como en $\mathrm{Chile}^{2}$, o aun en la misma España ${ }^{3}$.

Sin embargo, hubo un momento en que este tipo de composiciones llegó a la imprenta, lo que hizo surgir la distinción de "poesía popular impresa", teniendo, en el caso de Chile, a Bernardino Guajardo (1810?1886), Rosa Araneda (1861-1894), Daniel Meneses (1855-1909) y Juan Bautista Peralta (1875-1933) como sus más altos referentes y a la décima como su metro favorito. ${ }^{4}$ Impresas en pequeños libros o en pliegos que se vendían y voceaban en la calle, estas obras dejan de ser anónimas, aunque muchas veces se insertan en sus composiciones anónimos versos de la tradición o bien de otros puetas.

La poesía popular — cantada, recitada o impresa - influencia la obra de los poetas cultos (o ilustrados). Son algunos ejemplos los

${ }^{1}$ La versión del libro de Ernesto Mejía Sánchez, Romances y corridos nicaragüenses (Managua: Fondo de Promoción Cultural del Banco de América, 1976), viene acompañada de su respectiva partitura.

${ }^{2}$ Véanse las versiones que anota Julio Vicuña Cifuentes en Romances populares y vulgares recogidos de la tradición oral chilena (Santiago: Imprenta Barcelona, 1912). Una versión interpretada por Audolía Rivas, aparece en el disco Antología del folklore musical chileno volumen IV (Santiago: RCA Victor, 1965). Otra versión en el disco La tonada presentada por Violeta Parra (Santiago: Emi Odeón, 1959).

${ }^{3}$ Joaquín Díaz canta una versión en el disco Romances truculentos (Madrid: Movieplay, 1973).

${ }^{4}$ Rodolfo Lenz, Sobre la poesía popular impresa en Santiago de Chile (Santiago: Separata de los Anales de la Universidad de Chile, 1894). 
santiaguinos Eduardo de la Barra (1839-1900), con sus zamacuecas literarias, y Carlos Pezoa Véliz (1879-1908), con sus décimas y seguidillas.

Otro es Pablo de Rokha (1894-1968), nacido en Licantén, quien en su rupturista libro Los gemidos $(1922)^{5}$ incluye unas tonadas, entre varios poemas, que fueron musicalizados por Armando Carrera ${ }^{6}$ (18991949), aunque nunca grabados. También escribirá un "Romance proletario" y varias décimas. ${ }^{7}$

La misma Gabriela Mistral (1889-1957), nacida en Montegrande, está muy influenciada por la tradición de la poesía popular en su libro Ternura $(1924)^{8}$ aunque diga: "Estas canciones están harto lejos de las folclóricas que colman mi gusto". 9

Aun Pablo Neruda (1904-1973), nacido en Temuco, se deja atraer por la poesía popular al incluir cuecas literarias en su Canto General (1950) tituladas "Manuel Rodríguez"10.

${ }^{5}$ Pablo de Rokha, Los gemidos (Santiago: Editorial Cóndor, 1922).

${ }^{6}$ Ver "'Égloga' / Canciones de Chile a lo humano y a lo divino, musicalizadas en 1923, para el arpa y la guitarra por Armando Carrera", en Pablo de Rokha, Antología 1916-1953 (Santiago: Editorial Multitud, 1954), 541-548.

${ }^{7}$ Pablo de Rokha, Poemas rimados o asonantados (Santiago: Zig-Zag, 1966). Esta antología la realizó Luis Sánchez Latorre, alias Filebo.

${ }^{8}$ Algunos poemas de este libro fueron grabados por su autora en 1950 y aparecen en el disco Gabriela Mistral Reading her Own Poetry (Washington, D.C.: Library of Congress, 1977).

${ }_{9}$ Gabriela Mistral, En verso y prosa. Antología (Lima: Alfaguara, 2010). Queda también en evidencia la fascinación de Gabriela Mistral por el folclor, cuando colabora para que se publique el libro de los etnólogos franceses Georgette y Jacques Soustelle, Folklore chilien (París, Institut International de Coopération Intellectuelle, 1938), que ella misma prologa con el texto "Quelques mots sur les Araucans". El libro incluye desde cantos de machi hasta décimas de Bernardino Guajardo, traducidos al francés.

${ }^{10}$ Musicalizadas en 1955 tanto por Margot Loyola como por Vicente Bianchi. En su versión, Bianchi cambió el título a Tonadas de Manuel Rodríguez y fueron grabadas por Silvia Infantas y Los Baqueanos en el disco Música para la historia de Chile (Santiago: Emi Odeon, 1955). Las versiones de Margot Loyola aparecieron en el casete ¡Neruda vive! (Santiago: Sello Raíces, 1983) con una breve presentación del propio poeta. También el grupo Aparcoa las musicalizó en el disco compacto Aparcuecas (Santiago: Alerce, 2007). Esas versiones datan de la época en que el conjunto trabajó en el disco Canto general (Santiago: Phillips, 1971) con el propio Neruda, quien conoció esas musicalizaciones. 


\section{DOS}

En la posmoderna poesía de Nicanor Parra Sandoval, nacido en San Fabián de Alico en 1914, sería difícil escabullir la influencia de la poesía popular, siendo él integrante de una celebérrima familia de músicos. El exponente musical más importante de esta familia ha sido su hermana Violeta (1917-1967), recopiladora de cantos tradicionales y compositora de temas que terminaron por renovar la canción chilena en la década del 60.

Nicanor Parra, el mayor de sus hermanos, en varias entrevistas rememora a su padre y sus oficios de profesor y trovador, quien dominaba varios instrumentos. También recuerda a sus progenitores formando un dúo musical durante las reuniones familiares, entonando algunas de esas canciones que les escuchó desde niño, como "El pajarillo errante":11

Yo soy el pajarillo errante

Que ando perdido, que ando perdido

Dentro de mis enramadas

En pos de abrigo, en pos de abrigo
Alzo mi vuelo
Me traicionan mis alas, me traicionan mis alas
Ay, volar no puedo ${ }^{12}$

Violeta Parra, en su libro Cantos folklóricos chilenos, donde da testimonio de cómo recopiló algunos de sus cantos y refiere anécdotas de sus respectivos informantes, relata:

Los primeros cantos que llegaron a mis oídos fueron los que cantaba mi madre nacida y criada en el campo, Malloa, cerca de Chillán, y los que cantaba mi padre, hombre de ciudad, profesor de primeras letras y de música. El repertorio de mi padre estaba formado por habaneras, valses, tonadas y canciones pueblerinas, cantos de salón, románticos, característica esencial que distinguía

${ }^{11}$ Leonidas Morales, Conversaciones con Nicanor Parra (Santiago: Ediciones UDP, 2014). El compilador de estas conversaciones, en otro capítulo, describe que Nicanor tiene muy buena voz.

12 Versión del casete de Rosario Hueicha, Del canto y la tradición volumen II (Santiago: CBS Records Chile Ltda., 1990). 
los cantos urbanos de fines de siglo con los cantos folklóricos de la misma época ${ }^{13}$.

Este fragmento citado es del capítulo que le dedica a su madre, Clarisa Sandoval, donde da cuenta de algunas de las canciones que aprendió de ella y que Violeta llevara al disco. Esta madre hasta componía canciones; incluso una de sus cuecas, titulada "Libre fue la patria entera", la grabaron sus hijos Eduardo, Lautaro y Óscar, bajo el nombre de Los Viejos Parra:

Un 18 de septiembre

Libre fue la patria entera

Y lucharon como leones

O’Higgins y los Carrera

Celebramo' en el parque

Con mil ramadas

Y cantamos alegres

Cuecas, tonadas

Cuecas, tonadas, sí

La carretela

Adornada con flores

Hartas banderas

Vibra mi patria entera

Con sus banderas. ${ }^{14}$

De los hermanos de Nicanor, todos músicos, destaca Hilda (19161975), notable cuequera con quien Violeta grabó algunas canciones integrando el dúo Las Hermanas Parra durante los años 50. Además está Roberto (1921-1995) y su afamado disco Las cuecas de Roberto Pa$r r a .{ }^{15}$ En algunas de estas cuecas lo acompaña Violeta en la animación o "en los tarros, con lo cual no se rebaja su calidad artística, todo lo

${ }^{13}$ Violeta Parra, Cantos folklóricos chilenos (Santiago: Editorial Nascimento, 1979).

${ }^{14}$ Los Viejos Parra, 18 cuecas pa'l 18 (Santiago: RCA Victor, 1967).

${ }^{15}$ Roberto Parra, Las cuecas de Roberto Parra (Santiago: Emi Odeon, 1965). 
contrario; a ella le gustaba sus cuecas en tarro", declara Roberto cuando se editan esas cuecas en libro. ${ }^{16}$

Aun el propio Nicanor conoce los oficios del guitarrista. No sólo en una de las portadas de sus obras completas se puede ver una fotografía suya tañendo una guitarra, sino también en varias de sus entrevistas; así ocurre en un ejemplar de la revista La Bicicleta del año $1980^{17}$, donde se le pregunta si fuera un poema cuál sería y Nicanor responde el Martín Fierro ${ }^{18}$.

El dominio de la guitarra por parte de Nicanor, según su hermano Eduardo, fue tardío a diferencia de sus congéneres, que aprendieron a ejecutarla desde la infancia:

Porque la verdad es que a Nicanor siempre le gustó la música, pero nunca se lo demostró a sus hermanos, ni a nadie más. Sólo tiempo después, cuando volvimos de una gira con la Violeta, nos encontramos con la sorpresa de que Nicanor tenía su guitarra propia y que la tocaba. Nunca supe cómo aprendió, pero seguramente lo hizo como todos nosotros: solo. Y esa primera vez cantó con nosotros, y de ahí no paró más. Después, a la vuelta de otra gira, encontramos que Nicanor ya tenía un par de guitarras. Y aún hoy, cuando vamos a su casa, cantamos. No habiendo gente extraña, él toca con nosotros. $\mathrm{Y}$ es muy buen crítico, nos dice a nosotros, ante cualquier fallita, "cuidado con ese tono, cuidado con ese acorde", y le hacemos caso, porque sabemos que su oído es tremendo de bueno. ${ }^{19}$

Nicanor Parra es un declarado melómano. Baste citar aquella anécdota que refiere Mario Baeza (1916-1998) cuando empezó a recolectar firmas para la candidatura de Claudio Arrau (1903-1991) al Premio Nacional de Artes Musicales de 1983: 1989).

${ }^{16}$ Roberto Parra, Las cuecas del tío Roberto (Santiago: Taller Lican-Rumi,

17 Samuel Silva, "Parra en libre plática", revista La Bicicleta n. 6 (marzoabril 1980). La entrevista es precedida de algunos de sus poemas que hasta ese momento estaban inéditos.

${ }^{18}$ Obra del argentino José Hernández (1834-1886), cuya primera parte fue publicada en 1872 y su segunda, en 1879 .

19 Eduardo Parra, "Mi hermano Nicanor", revista The Clinic, octubre de 2004. 
La primera [firma] fue la de Nicanor Parra. Fui personalmente a su casa de La Reina a buscarla, e inmediatamente me dijo: "Por supuesto. Trae para acá la hoja, y si es chillanejo, mejor todavía". ${ }^{20}$

En otra oportunidad ha confesado: "Yo soy un melómano incurable, me interesa mucho la música, y uno de mis músicos favoritos es, naturalmente, Juan Sebastián Bach". ${ }^{21}$

Pero la fascinación por la música folclórica Nicanor la canalizó principalmente a través de su hermana Violeta, de quien en una época fue prácticamente su productor musical, imponiendo en ella la manera en que debía cantar y tocar la guitarra, y dándole la gran tarea de recopilar el auténtico canto tradicional chileno. La relación entre ambos hermanos fue tan estrecha que Nicanor Parra — como ha declarado en varias oportunidades - a veces sentía que con Violeta eran la misma persona; no en vano llegó a escribir el verso "La Violeta Parra soy yo". 22

Violeta, en su libro autobiográfico Décimas —escrito durante 1958 y 1959- hace rimar significativamente las palabras "folclor" y "Nicanor", después de contarnos que fue él quien la instó a escribir ese mismo libro:

Muda, triste y pensativa ayer me dejó mi hermano cuando me habló de un fulano muy famoso en poesía. ${ }^{23}$ Fue grande sorpresa mía cuando me dijo: Violeta, ya que conocís la treta

${ }^{20}$ Inés María Cardone, Claudio Arrau: lo que nunca se dijo de su viaje a Chile (Santiago: Fondo Cultural Diario La Tercera - Editorial Andrés Bello, 1984). Existe una hermosa foto donde están Claudio Arrau y Violeta Parra al centro, del brazo y sonrientes, acompañados por media docena de personas.

${ }^{21}$ René de Costa, Nicanor Parra: conversaciones de Chicago (1987, inédito).

${ }^{22}$ Nicanor Parra, "Acuérdense de mí”, suplemento Revista de Libros n. ${ }^{\circ} 209$, diario El Mercurio, 2 de mayo de 1993.

${ }^{23}$ Véase José Hernández, autor del Martín Fierro que Violeta leyó a instancias de su hermano. En su tema "El albertío", Violeta menciona uno de los tantos proverbios del Martín Fierro: “¿Y dónde irá el güey que no are?”. 
de la versá' popular, princípiame a relatar tus penurias "a lo pueta".

Válgame Dios, Nicanor, si tengo tanto trabajo que ando de arriba p'abajo desentierrando folclor ${ }^{24}$. $[\ldots]$

Nicanor Parra siempre se enorgullece - y con justa razón - de que él "inventó" a Violeta Parra, citando la frase que acuñó su hermana: "Sin Nicanor no hay Violeta".

El tipo de evolución musical que protagonizó Violeta Parra se puede considerar único en Chile. Quien da nociones para explicar este tipo de evolución es el músico Luis Advis (1935-2004), quien, a partir de ideas del teórico de origen húngaro Arnold Hauser (1892-1978), explica que el hecho folclórico — el arte del pueblo — se manifiesta sólo en su entorno natural. El arte popular, en cambio, responde a las exigencias de un público tendiente a la masificación, como el público que asiste a presenciar el trabajo de los folcloristas y su labor de muestreo o recreación del hecho folclórico. En el hecho folclórico puro, productor y consumidor están apenas separados porque ambos son parte de él; en la recreación del hecho folclórico, en cambio, el consumidor es pasivo. $^{25}$

Violeta Parra, proveniente de esta familia de cantores, vivenció hechos folclóricos aprendiendo y ejerciendo como cantora popular, al punto de que incluso se ganó la vida cantando en mercados, quintas de recreo y bares, interpretando los temas que conoció en su propio entorno. Pero después, aun viniendo de ese mundo, se dedica a recopilar cantos, a recrearlos, incluso a grabarlos, lo que la lleva ahora a ser una folclorista que hace recitales y que participa de la radiofonía. Y después viene su consagración como compositora de temas influenciados por

${ }^{24}$ Violeta Parra, Décimas: autobiografía en versos chilenos (Santiago: Ediciones Nueva Universidad, 1972). Algunas de estas décimas fueron grabadas, y póstumamente llevadas al disco: Violeta Parra, Décimas (Santiago: Alerce, 1976).

${ }^{25}$ Luis Advis, "El neopopulismo musical", revista Semanal de diario El Siglo, 3 de agosto de 1972 . 
el canto tradicional chileno, con temas como "Volver a los 17" y "La jardinera". Pero también quiere explorar los límites de la tradición en composiciones como sus "Anticuecas" o "El gavilán", 26 donde ella pretende alejarse de los moldes, pero lo hizo a tal punto que terminó rompiéndolos.

El caso de la evolución de la obra de Nicanor y su lugar en la historia de la poesía es bastante parecido. Nicanor es a la poesía lo que Violeta a la música. Nicanor Parra también vivenció hechos folclóricos. Y más tarde acompañó a su hermana en algunos de sus recorridos recopilando cantos. ${ }^{27} \mathrm{Y}$ con ese bagaje investiga acerca de la poesía popular impresa para escribir en sus comienzos a la usanza popular. Y con ese conocimiento llegó a escribir poemas como "El hombre imaginario" y libros como Sermones y prédicas del Cristo de Elqui. Pero el cambio a la música chilena que hizo Violeta fue sin quererlo y sin saberlo. Al contrario de Nicanor, quien realizó un cambio en el rumbo de la poesía a sabiendas.

"La Violeta siempre fue abajista, yo siempre fui arribista":28 impactante declaración de Nicanor, quien hace un juego de palabras con los términos "abajino" y "arribano", para explicar esa diferencia entre su hermana y él.

\section{TRES}

Con respecto a la poesía popular, Nicanor Parra en sus entrevistas cita libros clave que estudió: Romances populares y vulgares recogidos de la tradición oral chilena, de Julio Vicuña Cifuentes; Cómo se canta la poesía popular, de Desiderio Lizana, y Sobre la poesía popular impresa en Santiago de Chile, de Rodolfo Lenz. También declara haber

26 "La base rítmica, armónica y formal del folclor chileno de la zona central del país en su manifestación más generalizada, esto es, la dupla cueca-tonada, es llevada por Violeta Parra a un nivel de estilización y desarrollo desconocido y no sobrepasado hasta hoy", comenta a propósito de esta obra Miguel Letelier, "Reencuentro con Violeta Parra", diario El Mercurio, 26 de diciembre de 1999.

${ }^{27}$ Así lo cuenta la propia Violeta en una conferencia grabada el 14 de enero de 1960 y editada en el cedé Violeta Parra en el Aula Magna de Concepción (Santiago: Oveja Negra, 2010).

${ }^{28}$ Roberto Careaga C., "Nicanor Parra: 'La Violeta siempre fue abajista, yo siempre fui arribista", diario La Tercera, 13 de abril de 2004. 
analizado y agregado cuartetas a El contrapunto del mulato Tahuada con don Javier de la Rosa, unas coplas anónimas del siglo XIX. ${ }^{29}$

Así, desde esta seguidilla que inserta en una prosa intitulada "El ángel” (1936), la poesía popular cruza su obra:

Pardo juguete alegre

sangre serena

por si la ronda enciende

nueva azucena. ${ }^{30}$

En su primer - y renegado — libro Cancionero sin nombre (1937), la influencia de la poesía popular está aludida a partir del título mismo. Los cancioneros tradicionales, de origen español, son el repertorio de coplas anónimas que terminaron por nutrir el repertorio de los cantores populares.

El cancionero se diferencia de los romances en que estos últimos refieren hechos de épocas remotas o indeterminadas, mientras el cancionero lo integran las coplas tradicionales cuyos contenidos pueden aplicarse al presente. El español Melchor de Paláu (1842-1910) tiene sus definiciones:

El romancero es el ayer, es la estereotipación de nuestras hazañas, de nuestras leyendas y tradiciones, es el jugo no evaporado de nuestros caballerescos amores; eminentemente objetivo, conserva en sí el encanto de las lejanías, el aparato de la gloria, el nimbo de lo heroico, el dejo atractivo de lo que se va; los cantares son el hoy, son el siempre, son lo interno, lo sincero, lo pasional. Ayes, quejas, máximas, amenazas, ansias, consejos, burlas, plegarias y exageraciones de un pueblo constituyen su alma entera, lo revelan tal cual es, con sus animosas virtudes, con sus simpáticos defectos: autobiografía en que las venideras edades estudiarán sus costumbres, su lengua, sus amores, su filosofía y su religiosidad $[\ldots] .^{31}$

${ }^{29}$ Una versión de este contrapunto fue recompuesto por el poeta popular Nicasio García, quien vivió durante la segunda mitad del siglo XIX y la primera del XX. Otra versión del contrapunto fue llevada al disco en 1969 en la voz e instrumentación de Santos Rubio, Antología del folklore musical chileno volumen V (Santiago: RCA Victor, 1969). Antonio Acevedo Hernández relata el contrapunto e incluye una versión de las coplas en Leyendas chilenas (Santiago: Quimantú, 1971).

${ }^{30}$ Nicanor Parra, "El ángel (tragedia novelada)", en Revista Nueva (1936).

${ }^{31}$ Melchor de Paláu, "Prólogo", en Cantares populares y literarios (Barcelona: Montaner y Simón Editores, 1900). 
Si bien los cancioneros son anónimos, en este Cancionero sin nombre de Parra pasa algo curioso: quien no tiene nombre ahora es el propio cancionero que sí tiene un autor identificable.

La versificación de Cancionero sin nombre incluye dísticos octosílabos, alterando la forma clásica de la copla, que normalmente corresponde a los cuatro versos octosílabos o de seguidilla.

Así, desde su primera publicación, Parra suele intitular sus libros refiriéndose principalmente al aspecto formal que contiene su mensaje, y en segundo lugar a la temática de sus publicaciones; entonces, si nos atenemos a la mayoría de los títulos de sus libros, en éstos encontraremos versos, hojas, poemas, antipoemas, canciones, coplas, artefactos, sermones, prédicas, chistes, discursos, trabajos, obras. Pues Nicanor Parra no está preocupado por la unidad temática de cada libro, sino por su unidad estilística.

Así es como bautiza Poemas y antipoemas (1954) a su siguiente publicación tras su renegada opera prima. Este nuevo libro está separado en tres partes, que originalmente fueron tres libros distintos - "Cantos a lo humano y a lo divino", "Poemas" y "Antipoemas"- que obtuvieron los tres primeros premios de un mismo concurso literario de la época, aunque desconocemos cuál de éstos recibió el primer lugar. Así, en estos títulos se ve que Parra trabajaba por entonces en planos simultáneos a partir de la tradición de la poesía popular, de la tradición de la poesía culta ${ }^{32}$ y de la experimentación de los antipoemas ${ }^{33}$.

El libro comienza con "Sinfonía de cuna". El final de este poema es sumamente conocido:

Siga su camino,

Que le vaya bien,

Que la pise el auto,

Que la mate el tren.

Ya se acabó el cuento, Uno, dos y tres.

${ }^{32}$ Ilustrada, diría Hauser.

${ }^{33}$ Con respecto a la palabra "antipoema", Parra comenta que fue acuñada a partir del título Apoèmes, del poeta francés Henri Pichette (1924-2000), pues cuando la escribió "tampoco conocía el verso del poema de Huidobro, que se considera a sí mismo un antipoeta y mago". De Costa, Nicanor Parra. 
Recuerda la movida canción "Si te vas de mí", del argentino Domingo Rullo (1920-2001):

Adiós, adiós, adiós, que te vaya bien.

Amor, amor, que te agarre un carro que te parta un rayo que te mate un tren.

Y alude a los verbales juegos infantiles:

Vamos jugando a la ronda de San Miguel

el que se ríe se va al cuartel

una, dos y tres.

Un, dos, tres

momia es.

[...] yo no soy bonita

ni lo quiero ser

arriba la barca

una, dos y tres. ${ }^{34}$

Desde este poema inicial se distingue un elemento presente en gran parte de la poesía de Nicanor Parra: su carácter narrativo, a la manera de los romances definidos por Julio Vicuña Cifuentes como cuentos en verso. ${ }^{35}$

En la primera parte del libro hay otro texto en cuartetas, también hexasílabas: "Catalina Parra".

La segunda parte se inicia con el poema "Desorden en el Cielo", de una sola estrofa octosílaba y de rima pareada, forma muy recurrente del romance. Y se incluyen dos poemas más en cuartetas octosílabas, "San Antonio" y "Canción". 36

${ }^{34}$ Manuel Peña Muñoz, Para saber y cantar: el libro del folklore infantil chileno (Santiago: Ediciones Cerro Huelén, 1983).

35 Vicuña Cifuentes, Romances populares.

${ }^{36}$ Estos tres poemas fueron incluidos en el disco de Nicanor Parra, Poemas y antipoemas (Santiago: Emi Odeon, 1965). Por el lado A del disco, Parra declama algunos poemas de las dos primeras partes del libro y, por el reverso, algunos antipoemas de la tercera parte. 
El resto de los poemas del libro está construido con la métrica de la silva (versos heptasílabos y endecasílabos) o el verso libre, aún más en la tercera parte que es la de mayor extensión. Parra opina que "los endecasílabos son prácticamente lugares comunes del habla chilena"37 y en lo sucesivo recurrirá a ellos en la mayoría de sus textos con métrica.

En Poemas y antipoemas, el autor, a través de un mismo libro y sus tres estadios, termina por imponer el uso del lenguaje hablado que no abandonará jamás:

[...] he encontrado algunas justificaciones; por ejemplo, cuando me encontré con esta frase que circula mucho: la poesía debe ser la voz de la tribu. Entonces dije yo: ésta es la confirmación de aquella intuición. Porque cuando yo leía a un poeta como Hernández, cuando leí el Martín Fierro y me convencí - como estoy convencido ahora - de que Martín Fierro era el poema más grande de nuestro idioma, entonces vi también que se confirmaba esta intuición. Martín Fierro es un poema escrito en una lengua hablada, una lengua campesina, pero hablada. ${ }^{38}$

Pero Parra, en vez de buscar la lengua campesina, busca la lengua citadina. "Violeta y Nicanor, representan el campo y la ciudad, respectivamente", escribirá él mismo. ${ }^{39}$

$\mathrm{Su}$ siguiente libro, La cueca larga (1958), se relaciona con algunos hechos discográficos. Ese año y el siguiente aparecen dos discos de su hermana Violeta. En el primero de éstos, El folklore de Chile volumen $I I,{ }^{40}$ aparece una composición con letra de Nicanor Parra: "Cueca larga de los Meneses". Y en el siguiente disco, La cueca presentada por Violeta Parra, ${ }^{41}$ aparece el segundo pie de esta cueca.

La cueca presentada por Violeta Parra es el primer long play que contiene exclusivamente cuecas. Es decir, el disco es todo un hito de la industria musical chilena. ${ }^{42}$

${ }^{37}$ De Costa, Nicanor Parra.

38 Ídem.

39 Nicanor Parra, "Prólogo", en Roberto Parra, Décimas de la Negra Ester (Santiago: Ediciones Taller Nuevagráfica, 1980).

${ }^{40}$ Violeta Parra, El folklore de Chile volumen II (Santiago: Emi Odeon, 1958)

${ }^{41}$ La cueca presentada por Violeta Parra (Santiago: Emi Odeon, 1959).

42 Por su parte, una edición de La cueca larga viene acompañada de un disco, donde la obra viene íntegra en la recitación de Roberto Parada y acompañamiento de guitarra por Violeta Parra (Santiago: Editorial Universitaria, 1966). 
El poema "La cueca larga" del libro homónimo, consta de su cuarteta inicial, con alrededor de cuarenta seguidillas, y un dístico final. Sus seguidillas, a su vez, están divididas en cuatro secciones.

La primera musicalización de Violeta de este poema (1958) corresponde a la cuarteta inicial y a la primera sección de las seguidillas. La segunda musicalización (1959) corresponde a una nueva cuarteta no incluida en el poema editado, seguida de la tercera y cuarta partes de las seguidillas, incluyendo ahora el dístico final. La nueva cuarteta dice:

\section{Señores y señoritas}

Aquí empieza el zapateao

Pásenle un traguito al que baila

Que ya cae desmayao. ${ }^{43}$

Del porqué, después de la renovación de Poemas y antipoemas, Nicanor Parra decide publicar este libro, lo explica así:

Ahora, ¿por qué escribí La cueca larga? Porque tenía sangre en el ojo también; yo había empezado con un libro como Cancionero sin nombre, que es un libro confuso. Yo parto del romance artístico español y después me doy cuenta de que se puede partir desde mucho más atrás, de algo mucho más auténtico que es el "romancero" o que es la poesía popular. Entonces dije caramba, cometí un error muy grande, porque en el romance artístico la poesía popular ya está debilitada. [...]

[A Cancionero sin nombre] le falta fuerza y le falta penetración, y le falta realidad chilena. En cambio, en La cueca larga yo me apodero de la poesía popular chilena. ${ }^{44}$

Antes de este libro apareció la nutrida antología La cueca, de Antonio Acevedo Hernández. ${ }^{45}$ Ahí aparece una "Cueca larga del 19". La cueca de Parra dice en una de sus seguidillas:

${ }^{43}$ Hay una tercera musicalización pero ya no con melodía de cueca, grabada alrededor de 1960, donde están cantadas la cuarteta inicial y secciones de la primera parte de las seguidillas. Aparece en el disco compacto de Violeta Parra, Composiciones para guitarra (Santiago: Warner Music, 1999).

${ }^{44}$ De Costa, Nicanor Parra.

45 Antonio Acevedo Hernández, La cueca: orígenes, historia, antología (Santiago: Editorial Nascimento, 1953). 
Cae el agua y no cae

Llueve y no llueve

Ésta es la cueca larga

Del diecinueve.

El libro La cueca larga de Parra contiene cuatro poemas, entre ellos otro de los textos musicalizados por su hermana Violeta, "El chuico y la damajuana", que aparecerá en 1961 en el disco Toda Violeta Parra ${ }^{46}$ disco que, a su vez, incluye otra composición con letra de Nicanor (que sin embargo nunca incluirá en un libro): "El hijo arrepentido".

Otro texto de Nicanor grabado por su hermana y no publicado es "La cueca de los poetas". ${ }^{47}$ El final de este cueca - "Corre que ya te agarra / Nicanor Parra"- con el tiempo ha sido cambiado por el propio autor a "Corre que ya te agarra / Violeta Parra", reivindicando el valor de Violeta como poeta.

La cueca fue una forma métrica que siempre fascinó a Parra. Mucho antes de la cueca de Neruda del Canto general, Parra tenía anunciado un libro que nunca se publicó: Tonadas y cuecas. Incluso ganó un concurso de cuecas literarias en la década del cuarenta y tuvo un proyecto muy posterior que denominó "Cueca a cámara lenta". ${ }^{48}$

Además de las musicalizaciones de su hermana, la presencia de Violeta es recurrente en la obra de Nicanor. Por ejemplo, Parra recita su poema "Defensa de Violeta Parra" al inicio del disco de su hermana Recordando a Chile.$^{49} \mathrm{El}$ poema más tarde aparece en su libro recopilatorio Obra gruesa (1969), donde agrega unos versos finales:

Esto es lo que quería decirte

Continúa tejiendo tus alambres

Tus ponchos araucanos

Tus cantaritos de Quinchamalí

Continúa puliendo noche y día

Tus toromiros de madera sagrada

${ }^{46}$ Toda Violeta Parra (Santiago: Emi Odeon, 1961).

${ }^{47}$ Las últimas composiciones de Violeta Parra (Santiago: RCA Victor, 1966).

${ }^{48}$ De Costa, Nicanor Parra.

${ }^{49}$ Violeta Parra, Recordando a Chile (Santiago: Emi Odeon, 1965). 


\section{Sin aflicción}

$$
\text { sin lágrimas inútiles }
$$

$\mathrm{O}$ si quieres con lágrimas ardientes

$Y$ recuerda que eres

Un corderillo disfrazado de lobo.

Hay aun otra cuarteta de Nicanor, no incluida en libro, que aparece en la contracarátula del disco La tonada presentada por Violeta Parra: ${ }^{50}$

En el centro de la mar

Suspiraba una guitarra

Y en el suspiro decía

Que cante Violeta Parra ${ }^{51}$

\section{CUATRO}

Parra, a pesar de que buscó innovar libro a libro, nunca abandonará los recursos que le ofrece la poesía popular.

En la compilación de su poesía Obra gruesa (1969) aparecen algunos poemas nuevos suyos no recogidos antes en libro; entre ellos "Los dos compadres", de versos octosílabos y rima libre.

En su siguiente libro Emergency poems (1972) hay dos poemas compuestos también de versos octosílabos y rima libre, "Preguntas y respuestas" y "Había una vez un monje", aunque en este segundo inserta un par de jocosas cuartetas rimadas.

En su caja de tarjetas Artefactos (1972), donde pretende prescindir de la página para que los poemas sean leídos al azar, Parra vuelve a la figura de su hermana, dedicándole tres poemas. También hay un final de cueca; el artefacto de tres líneas dice:

50 Violeta Parra, La tonada presentada por Violeta Parra (Santiago: Emi Odeon, 1959).

${ }^{51}$ En esa misma contracarátula, aparece una copla de Neruda:

...entró Violeta Parrón

violeteando la guitarra, guitarreando el guitarrón, entró la Violeta Parra... 
Fin de cueca

No creo en redentores

$\mathrm{Ni}$ en salvadores.

En una nueva caja de tarjetas, Chistes parra desorientar a la polieía poesía (1983), otra vez hay alusiones a su hermana:

Violeta Parra

madre de la patria

En otra tarjeta se lee:

mi papá con mi mamá

se agarraon a patá

en la calle libertá

(recuerdo de infancia)

En sus conversaciones con Leonidas Morales, Parra comenta que esa estrofa era parte de uno de los juegos de su niñez.

Otro texto:

comenzaré con una copla chilena

vale decir española:

por ser la primera vez

que en esta casa yo canto

gloria al padre gloria al hijo

gloria al espíritu santo

Entre otras incursiones está la décima que se inserta como parte de su prólogo a la edición de Décimas de la Negra Ester (1980) de su hermano Roberto.

Brindo x la Negra Ester

y x el pobre Roberto

que todavía anda muerto

de amor x esa mujer

Así suele suceder

en el jardín del honor

ella murió de dolor 
al verse tan poca cosa

indigna de ser su esposa

y él se morirá de amor. ${ }^{52}$

En ese mismo prólogo describe la obra de su hermano Roberto y destaca su lugar como músico cuequero, especialmente sus "cuecas choras". 53

En su libro Poesía política (1983) vuelve a aludir a la figura de su hermana. Y en otro poema cambia de contexto y parodia una inocente canción folclórica infantil, al ponerle el título "Canción protesta":

Los pollitos dicen

pío pío pío

porque tienen hambre

porque tienen frío. ${ }^{54}$

Volverá a parodiar esta misma canción en uno de sus Discursos de sobremesa (2006), al usar el epígrafe:

Los pollitos dicen

Río Bío Bío. ${ }^{55}$

En la misma senda de Poesía política, se encuentra su poema Coplas de Navidad (1983) que parte con el quizá único epígrafe literal que ha ocupado Parra en su obra (y que volverá a repetir en La Sagrada Familia (rap), de 1997):

San José mira a la Virgen

la Virgen a San José

el niño mira a los 2

y se sonríen los $3 .^{56}$

52 Roberto Parra, "Prólogo".

${ }^{53}$ Acevedo Hernández, en La cueca, describe la cueca chora como la cueca del hampa santiaguina.

54 Ésta es una antigua canción infantil que antologó el músico y folclorista Ismael Parraguez, en Poesías infantiles (Santiago: Casa Editorial Minerva, 1920).

${ }^{55}$ Nicanor Parra, "Discurso del Bío-Bío", en Discursos de sobremesa (Santiago: Ediciones Universidad Diego Portales, 2006), 195.

${ }^{56}$ Nicanor Parra, Coplas de Navidad (Santiago: Talleres de Ediciones Minga, 1983). 
Esta estrofa pertenece a la canción "Alulú" grabada por su hermana Violeta, ${ }^{57}$ quien también compuso un villancico en décimas, cuyo comienzo de una de sus estrofas dice:
Ahí está la Virgen pura
al lado de San José, con el niñito son tres, se miran con gran ternura. ${ }^{58}$

En Coplas de Navidad Parra parodia algunas estrofas de villancicos chilenos, insertando temas referidos a la época de dictadura en que se compuso el poema:
Al cielo le doy las gracias
y al niño Jesús le pido
que vuelva la democracia
abajo la aristocracia. ${ }^{59}$

En su siguiente libro, Hojas de Parra (1985), los cruces con la poesía popular son más variados. "Memorias de un ataúd" podría ser un muy entretenido romance, a no ser por su métrica libre. "La venganza del minero" está más en la línea del romance, debido a su métrica octosilábica de rima pareada. "Yo me sé tres poemas de memoria" remite a los romances orales que provienen de impresos, como algunos antologados por Vicuña Cifuentes; en estos poemas memorizados impostadamente, Parra cambia algunas palabras puntuales, tal como se suple en la oralidad alguna palabra olvidada. "Murió" es una suma de frases típicas del habla chilena. "El hombre imaginario" se inspira en la métrica de la seguidilla (propia de la cueca) para lograr su cadencia. ${ }^{60}$ "Amor no correspondido" es un huaino que concluye con la interjección "huifayayay" en vez del "palomitay" con que terminan las estrofas que lo pre-

${ }^{57}$ Violeta Parra, Chants et Danses du Chili II (París: Le Chant du Monde, 1956).

58 Este tema nunca lo grabó Violeta, pero quien sí lo hizo fue Víctor Jara (1932-1973) para uno de los discos del conjunto Cuncumén, en Villancicos chilenos (Santiago: Emi Odeon, 1959).

${ }^{59}$ Nicanor Parra, "Coplas de Navidad".

${ }^{60}$ Floridor Pérez, "Nicanor Parra: Hojas de Parra", revista El Espíritu del Valle n. ${ }^{\circ} 1$, diciembre de 1985. 
ceden. ${ }^{61}$ "El poeta y la muerte" es un divertido poema con coprolalias versificado a la manera de Cancionero sin nombre, es decir, cuartetas y dísticos octosílabos con rimas pareadas.

El poema "El huaso Perquenco", también incluido en Hojas de Pa$r r a$, es una adaptación a un poema tradicional por el cual Nicanor siente una especial predilección. Su hermana Violeta grabó el romance ${ }^{62}$, y a este respecto relata la folclorista Gabriela Pizarro (1932-1999):

Violeta tomó el texto de este romance de la colección de Julio Vicuña Cifuentes, Romances populares y vulgares, editado en 1912, y le puso música.

Le atrajo, tal vez, esta sintética interpretación de un bandido campesino chileno, legendario o no, habitante de lo que una vez fuera "la frontera" desplazada sucesivamente hacia el Sur. ${ }^{63}$

Quizá lo mismo fascinó a su hermano.

En una nueva publicación, la antología de Parra Poemas para combatir la calvicie (1993), vuelve a aparecer la figura de su hermana en el ingenioso anagrama "Violeta Parra/ Ave porta lira" ${ }^{64}$ Allí inserta también un par de cuartetas octosílabas irresistibles de citar:

Yo soy Lucila Alcayaga

Alias Gabriela Mistral

Primero me gané el Nobel

Y después el Nacional

A pesar de que estoy muerta

Me sigo sintiendo mal

Porque nunca me entregaron

El Premio Municipal. ${ }^{65}$

${ }^{61}$ Musicalizado por Lautaro Parra, fue grabado por Hilda Parra con el título “Amor no correspondido", en su disco Hilda canta a Violeta (Santiago: RCA Victor, 1970).

62 Grabado durante 1961, el tema apareció en disco en la antología Violeta Parra 3 (Santiago: Emi Odeon, 1977).

${ }^{63}$ Gabriela Pizarro Soto, Cuaderno de terreno: apuntes sobre el romance en Chile (Santiago: Autoediciones Populares - Taller Lican-Rumi, 1987).

${ }^{64}$ Nicanor Parra, “Anagramas”, en Poemas para combatir la calvicie (Santiago: Fondo de Cultura Económica, 1999), 314.

${ }^{65}$ Nicanor Parra, "Epitafio", en Poemas para combatir la calvicie, 307. 
El 2004, la revista The Clinic dedica un número especial a Parra. Ahí aparecen las "Coplas de San Fabián" y "Las coplas del tartamudo", donde se inclina por lo vulgar, tal como ya lo había hecho con las coprolalias de los Artefactos o del poema "El poeta y la muerte". Entre "Las coplas del tartamudo", se lee:

Chupa el pi-

Chupa el picaflor la rama

$[\ldots]$

Por la ra-

Por la razón o la fuerza

En estas últimas coplas, Parra utiliza el mismo método del conocido vals "La pirilacha", que está basado en el folclor:

Tu madre es pu-

Tu madre es pura limpieza

$[\ldots]^{66}$

Aun hay otro poema suyo musicalizado y nunca llevado a libro, "La vieja verde", y, de acuerdo con el disco donde aparece ${ }^{67}$, se trata de una tonada:

Me enamoré de una vieja

Por interés de la plata

Pero me anduvo saliendo

El tiro por la culata

A la primera palabra

Le pedí para un pencazo

Me dijo mijito lindo

Acaso me da un abrazo

A la segunda palabra

Le pedí quinientos pesos

Me dijo mijito lindo

Acaso me dai un beso

${ }^{66}$ Del single de Nilda Moya, La pirilacha (Santiago: Sol de América, s/f).

${ }^{67}$ Musicalizado y grabado por Ángel Parra en el disco Ángel Parra y el tocador afuerino (Santiago: Arena, 1967). 

A la tercera palabra
Le pedí para un abrigo
Me dijo guacho culebra ${ }^{68}$
Cuando te casís conmigo
No me quedó más remedio
Que hacérmele bien el tonto
Le dije viejita linda
Casémonos lo más pronto
Y cuando ya nos casamos
Buena con la vieja tuerta
Resulta que no tenía
$\mathrm{Ni}$ adónde caerse muerta
Señores y señoritas
No se casen por la plata
Porque les puede salirles
El tiro por la culata.

\section{CINCO}

Debido a que los hechos folclóricos disminuyen en razón del progreso de las comunicaciones, en la sociedad moderna se empieza a sustituir lo popular por lo masivo. Parra toma nota de la situación y ocupa cada vez más elementos de la cultura de masas en su poesía a medida que la consagración de su obra aumenta:

Su texto "USA: donde la libertad es una estatua", mostrado en una pantalla luminosa nada menos que en Times Square de Nueva York. Don Nicanor participando en un comercial de televisión donde declamó: "Cero problema, yo también tomo leche", parodiando su propio poema "Filosofía natural" 69 . Asimismo, se elaboran poleras estampadas con sus poemas en una "edición limitada".

Incluso Parra ha incursionado en el poema de circunstancia. Por ejemplo, en un folleto de la feria del libro de 1999 aporta con un texto: "STOP WRITING / Ha llegado la hora de leer". También no ha temido

${ }^{68}$ La expresión "guacho culebra" es propia de su hermana Violeta. Véase la correspondencia de Violeta en el libro de Isabel Parra, El libro mayor de Violeta Parra (Madrid: Meridión, 1985).

69 Nicanor Parra, "Filosofía natural", en revista Manuscritos (Departamento de Estudios Humanísticos de la Universidad de Chile, 1975). 
incluir en sus versos a personajes de la contingencia, tales como el cantante "cebolla" Zalo Reyes, la ex Miss Universo Cecilia Bolocco o el torturador guatón Romo.

"Yo quiero, en la actualidad, que la poesía mía sea apreciada por el común de los mortales"70 es la máxima del propio Parra, por eso buscó sus influencias en lo popular y lo masivo, y en asimilar lo que hacen y dicen los demás.

Su obra es la de un hábil escritor que buscó la originalidad, teniendo como punto de partida elementos que estaban al alcance de su mano. Para qué ir más lejos:

Raras veces hago descubrimientos, sino que encuentro las cosas hechas, o sea, esto es más poesía encontrada que otra cosa, yo no me estrujo el cerebro como si fuera la teta de una vaca. ${ }^{71}$

En esta senda, y como elemento de su poesía, desde su libro compilatorio Obra gruesa (1969) empiezan a aparecer reproducciones de manuscritos del autor, incluyendo hasta los impostados borrones y correcciones. Esta modalidad se hará costumbre en varios de sus siguientes libros, integrando su propia caligrafía a su obra. ${ }^{72}$ En efecto, pues así escribe el hombre de la calle, como los garabatos que se encuentran en los baños públicos, donde es posible hallar frases como ésta, que Parra sublima:

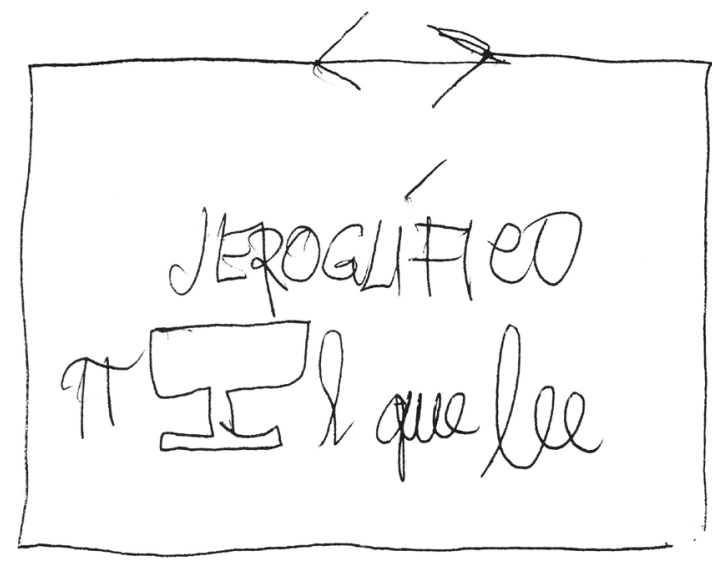

${ }^{70}$ De Costa, Nicanor Parra.

${ }^{71}$ De Costa, Nicanor Parra.

${ }^{72}$ Existe una fuente tipográfica basada en la caligrafía del poeta, que se llama Nicanor, desarrollada especialmente para un documental que se le dedica. 
En sus Obras públicas (2006) incluye este coprolálico "Jeroglífico" que demuestra su frase:

Admiro a muchos poetas y al hombre de la calle en especial. Parece que el poeta más grande de todos es el hombre de la calle; de él estoy alimentándome ordinariamente, o sea, del interlocutor. ${ }^{73}$

Como en el hecho folclórico puro, donde productor y consumidor son inseparables.

Así, la poesía de Parra se ha movido de lo popular a lo masivo, una evolución que hace aún más atractivo su aporte a la poesía contemporánea.

\section{REFERENCIAS}

\section{Textos}

Acevedo Hernández, Antonio. La cueca: orígenes, historia, antología. Santiago: Editorial Nascimento, 1953.

—. Leyendas chilenas. Santiago: Quimantú, 1971.

Advis, Luis. "El neopopulismo musical”. Revista Semanal de diario El Siglo, 3 de agosto de 1972.

Cardone, Inés María. Claudio Arrau: lo que nunca se dijo de su viaje a Chile. Santiago: Fondo Cultural Diario La Tercera - Editorial Andrés Bello, 1984.

Careaga C., Roberto. "Nicanor Parra: 'La Violeta siempre fue abajista, yo siempre fui arribista"”. Diario La Tercera, 13 de abril de 2004.

De Costa, René. Nicanor Parra: conversaciones de Chicago. 1987 (inédito).

De la Barra, Eduardo. Rimas chilenas. París: Garnier Hermanos, 1890.

De Paláu, Melchor. "Prólogo", en Cantares populares y literarios. Barcelona: Montaner y Simón Editores, 1900.

De Rokha, Pablo. Los gemidos. Santiago: Editorial Cóndor, 1922.

—. Antología 1916-1953. Santiago: Editorial Multitud, 1954.

De Rokha, Pablo \& Luis Sánchez Latorre "Filebo" (antologador). Poemas rimados o asonantados. Santiago: Zig-Zag, 1966.

Hernández, José. Martín Fierro. Barcelona: Conaculta - Fondo de Cultura Económica, 2001.

Lenz, Rodolfo. Sobre la poesía popular impresa en Santiago de Chile. Santiago: Separata de los Anales de la Universidad de Chile, 1894.

Letelier, Miguel. "Reencuentro con Violeta Parra". Diario El Mercurio, 26 de diciembre de 1999.

\footnotetext{
${ }^{73}$ De Costa, Nicanor Parra.
} 
Lizana, Desiderio. Cómo se canta la poesía popular. Santiago: Imprenta Universitaria, 1912.

Mejía Sánchez, Ernesto. Romances y corridos nicaragüenses. Managua: Fondo de Promoción Cultural del Banco de América, 1976.

Mistral, Gabriela. En verso y prosa. Antología. Lima: Alfaguara, 2010.

Morales, Leonidas. Conversaciones con Nicanor Parra. Santiago: Ediciones UDP, 2014.

Parra, Eduardo, “Mi hermano Nicanor”. Revista The Clinic, octubre de 2004.

Parra, Isabel. El libro mayor de Violeta Parra. Madrid: Meridión, 1985.

Parra, Nicanor. "El ángel (tragedia novelada)". En Revista Nueva, 1936.

—. "Filosofía natural". Revista Manuscritos, Departamento de Estudios Humanísticos de la Universidad de Chile, 1975.

- "Prólogo", en Roberto Parra, Décimas de la Negra Ester. Santiago: Ediciones Taller Nuevagráfica, 1980.

—. Coplas de Navidad. Santiago: Talleres de Ediciones Minga, 1983.

—. "Acuérdense de mí". Suplemento Revista de Libros n. ${ }^{\circ}$ 209, diario El Mercurio, 2 de mayo de 1993.

- Poemas para combatir la calvicie. Santiago: Fondo de Cultura Económica, 1999.

—. Discursos de sobremesa. Santiago: Ediciones Universidad Diego Portales, 2006.

- Obras completas \& algo + / Vol. I. Barcelona: Galaxia Gutenberg - Círculo de Lectores, 2006.

- Obras completas \& algo + / Vol. II. Barcelona: Galaxia Gutenberg - Círculo de Lectores, 2011.

Parra, Roberto. Décimas de la Negra Ester. Santiago: Ediciones Taller Nuevagráfica, 1980.

—. Las cuecas del tío Roberto. Santiago: Taller Lican-Rumi, 1989.

Parra, Violeta. Décimas: autobiografía en versos chilenos. Santiago: Ediciones Nueva Universidad, 1972.

- Cantos folklóricos chilenos. Santiago: Editorial Nascimento, 1979.

Parraguez, Ismael. Poesías infantiles. Santiago: Casa Editorial Minerva, 1920.

Peña Muñoz, Manuel. Para saber y cantar: el libro del folklore infantil chileno. Santiago: Ediciones Cerro Huelén, 1983.

Pérez, Floridor. "Nicanor Parra: Hojas de Parra". Revista El Espíritu del Valle n. ${ }^{\circ} 1$, diciembre de 1985.

Pizarro Soto, Gabriela. Cuaderno de terreno: apuntes sobre el romance en Chile. Santiago: Autoediciones Populares - Taller Lican-Rumi, 1987.

Silva Castro, Raúl. Carlos Pezoa Véliz (1879-1908). Santiago: Editorial Universitaria, 1964. 
Silva, Samuel. "Parra en libre plática". Revista La Bicicleta ${ }^{\circ}$ 6, 3 de abril de 1980.

Soustelle, Georgette \& Jacques Soustelle. Folklore chilien. París: Institut International de Coopération Intellectuelle, 1938.

Vicuña Cifuentes, Julio. Romances populares y vulgares recogidos de la tradición oral chilena. Santiago: Imprenta Barcelona, 1912.

\section{$\operatorname{Discos}^{74}$}

Cuncumén. Villancicos chilenos. Santiago: Emi Odeon, 1959.

Díaz, Joaquín. Romances truculentos. Madrid: Movieplay, 1973.

Infantas, Silvia y Los Baqueanos. Música para la historia de Chile. Santiago: Emi Odeon, 1955.

Los Viejos Parra. 18 cuecas pa'l 18. Santiago: RCA Victor, 1967.

Mistral, Gabriela. Gabriela Mistral Reading her Own Poetry. Washington, D.C.: Library of Congress, 1977.

Moya, Nilda. "La pirilacha". Santiago: Sol de América, s/f. ${ }^{75}$

Parra, Ángel. Ángel Parra y el tocador afuerino. Santiago: Arena, 1967.

Parra, Hilda. Hilda canta a Violeta. Santiago: RCA Victor, 1970.

Parra, Nicanor. Poemas y antipoemas. Santiago: Emi Odeon, 1965.

—. La cueca larga, en la recitación de Roberto Parada y acompañamiento de guitarra por Violeta Parra. Santiago: Editorial Universitaria, $1966 .^{76}$

Parra, Roberto. Las cuecas de Roberto Parra. Santiago: Emi Odeon, 1965.

Parra, Violeta. Chants et Danses du Chili II. París: Le Chant du Monde, 1956. ${ }^{77}$

—. El folklore de Chile volumen II. Santiago: Emi Odeon, 1958.

—. La cueca presentada por Violeta Parra. Santiago: Emi Odeon, 1959.

—. La tonada presentada por Violeta Parra. Santiago: Emi Odeon, 1959.

—. Toda Violeta Parra. Santiago: Emi Odeon, 1961.

- Recordando a Chile. Santiago: Emi Odeon, 1965.

—. Las últimas composiciones de Violeta Parra. Santiago: RCA Victor, 1966.

—. Décimas. Santiago: Alerce, 1976.

—. Violeta Parra 3. Santiago: Emi Odeon, 1977.

Rubio, Santos. Antología del folklore musical chileno volumen V. Santiago: RCA Victor, 1969.

Varios intérpretes. Antología del folklore musical chileno volumen IV. Santiago: RCA Victor, 1965.

\footnotetext{
${ }^{74}$ Discos long play, salvo donde se indique otra cosa.

${ }^{75}$ Single.

${ }^{76}$ Extended play. Viene acompañado del libro.

${ }^{77}$ Extended play.
} 


\section{Casetes}

Hueicha, Rosario. Del canto y la tradición volumen II. Santiago: CBS Records Chile Ltda., 1990.

Varios intérpretes. ¡Neruda vive! Santiago: Sello Raíces, 1983.

\section{Discos compactos}

Aparcoa. Aparcuecas. Santiago: Alerce, 2007.

Parra, Violeta. Composiciones para guitarra. Santiago: Warner Music, 1999.

- Violeta Parra en el Aula Magna de Concepción. Santiago: Oveja Negra, 2010. EP 